\title{
Determinants of Debt Financing and Their Moderating Role to Leverage-Performance Relation: An Emerging Market Review
}

\author{
Muhammad Ali Jibran Qamar ${ }^{1}$, Umar Farooq ${ }^{2}$, Hamayun Afzal ${ }^{1}$ \& Waheed Akhtar ${ }^{1}$ \\ 1 Department of Management Sciences/ Center of Islamic Finance, COMSATS Institute of Information \\ Technology, Lahore, Pakistan \\ ${ }^{2}$ Department of Management Sciences, Fast National University, Faisalabad, Pakistan \\ Correspondence: Muhammad Ali Qamar, Room 121, Faculty Block, Department of Management Sciences/ Center \\ of Islamic Finance, Defence Road, Off Raiwind Road, COMSATS Institute of Information Technology, Lahore, \\ Tel: 92-333-400-8995. E-mail: majqamar@gmail.com
}

Received: March 11, 2016

Accepted: April 21, 2016

Online Published: April 25, 2016

doi:10.5539/ijef.v8n5p300

URL: http://dx.doi.org/10.5539/ijef.v8n5p300

\begin{abstract}
This study explored the determinants of debt financing and their moderating role to the leverage-performance relation in case of 304 Pakistani Nonfinancial firms listed with the Pakistan Stock Exchange. Results revealed that larger, high liquid and more tangible firms deployed least debt ratio on average, while less liquid and less tangible firms did conversely. It is also found that more debt borrowing by less liquid firms and less borrowings by larger and more liquid firms is not favourable decision and managers need to revise their financing policy. The results also suggested that debt borrowings least affect firms' profits for larger, high liquid, less tangible and high growth oriented firms. Hence, this research provides practical solutions for financial managers by exploring if managers are following right mix of securities and when debt borrowings is a most favourable option of financing.
\end{abstract}

Keywords: debt financing, moderation, leverage, financial performance

\section{Introduction}

Capital structure is defined as mix of debt and equity, issued to meet firm's financing needs (Brealey \& Mayers, 2003). From the last few decades, these financing decisions have been given special attention due to their close relation with firm value. Searching "capital structure" as keyword in title on Google Scholar till 2015 provides 10,200 studies, including 7,020 published during 2005-2015. These numbers could also increase when search with other related terms such as leverage or debt financing. This literature of capital structure primarily focuses on two research objectives. First category tried to explore the consequences of capital structure (Horizons et al., 2010; Zaher, 2010; Zeitun \& Tian, 2007 etc). These studies tried to explore direct impact of debt and equity financing on firms' performances. Searching "capital structure" along with profitability and other related terms in title till 2015, 1210 studies were found and show that leverage-performance studies are also immense in numbers.

Once the significance of capital structure is affirmed, finding its determinants have also become motivation for researchers. Therefore, second research category deals with the determinants of capital structure (Boateng, 2004; Karadeniz et al., 2009; Sheikh \& Wang, 2011 etc.). On Google Scholar 1,130 studies were found while searching two terms "capital structure" and "determinants" simultaneously in title till 2015. These studies explored various firm specific (González \& González, 2012; Mouamer, 2011; Sheikh \& Wang, 2011 etc.) and macroeconomic factors (Bokpin \& Arko, 2009; Cook \& Tang, 2010; Mackay \& Phillips, 2005 etc.) that could affect firm's financing choices. However, results of firm specific factors are more valuable and explore that in practice which kinds of firms deployed what mix of securities. For instance, Sheikh and Wang (2011) found positive relation between size and debt that shows in practice larger firms are deploying more debt.

However, an important thing to know is that whether debt financing in response to these firm specific determinants is optimal or not. For instance, if larger firms are deploying more debt, then is it optimal decision for these larger firms? Similarly, if smaller firms are deploying less debt then is it optimal decision for them? These are more practical research questions and intends to answer these questions from three perspectives in the 
context of developing economies like Pakistan.

1) What are firm specific determinants of debt financing in case of Nonfinancial firms in developing countries like Pakistan?

2) Financing decisions in response to selected determinants are optimal or not?

3) For which kind of companies, debt borrowings are most profitable option?

Thus, the outcome of this research has strong practical implications that will let financial managers to know if they are following right mix of securities and when debt borrowing could maximize their value.

\section{Literature Review}

Modigliani and Miller (1958) argue that the value of a firm is not affected by its capital structure within perfect market. However, this theory is criticized due to non-existence of perfect market that makes capital structure decisions more relevant to firm value (Myers, 1984). Consequently, the capital structure is being studied in real world practices and relevancy theories are devised. Trade-off theory, agency theory and pecking order are prominent relevancy theories in this respect. Trade-off theory argued that firms can maximize their value, though targeting optimal debt ratio where its tax benefits are maximum at minimum cost (Masulis, 1988). Agency theory also supports the relevancy of capital structure and postulates that high level of debt ensures better managerial performance as the probability of bankruptcy creeps up (Jensen \& Meckling, 1976). Conversely, pecking order theory emphasizes on hierarchy of preferred financing options that starts with internal funds to debt to share capital (Myers \& Majluf, 1984).

Thus, trade-off and agency theories view debt as positive connotation while pecking order theory does conversely. Considering these theories, researchers have explored leverage-performance relation in the context of both developed and developing economies. However, due to inefficient and irregularities of capital markets in developing economies leverage-performance relation becomes more critical (Ebaid, 2009). Less efficient markets also creates more asymmetric information and irregularities (Eldomiaty, 2007). Similarly, dynamic environment is another feature of developing economies that increase risk and affects financing options. These adverse features could be the reason of negative leverage-performance relation in developing economies as found by many of prior studies given in Table 1 .

Table 1. Leverage-performance relation in developing countries

\begin{tabular}{lcc}
\hline Author and Year & Country & Relation \\
\hline (Hailu, 2015) & Ethiopia & - \\
(Hedayatzadeh, 2015) & Tehran & - \\
(Alipour \& Pejman, 2015) & Iran & - \\
(Boadi \& Li, 2015) & Ghana & - \\
(Vătavu, 2015) & Romania & - \\
(Mule \& Mukras, 2015) & Kenya & - \\
(Nakhaei \& Jafari, 2015) & Tehran & - \\
(Nguyen \& Nguyen, 2015) & Vietnam & - \\
(Ramadan \& Ramadan, 2015) & Jordan & - \\
(Resić, Mangafić, \& Peric, 2015) & Bosnia and Herzegovina & - \\
(Rouf, 2015) & Bangladesh & - \\
(Vithessonthi \& Tongurai, 2015) & Thailand & - \\
(Akinlo \& Asaolu, 2012) & Nigeria & - \\
(Ebaid, 2009) & Egypt & - \\
(Chen, Chen, Liao, \& Chen, 2009) & Taiwan & - \\
(Memon, Bhutto, \& Abbas, 2012) & Pakistan & - \\
(Umar, Tanveer, Aslam, \& Sajid, 2012) & Pakistan & - \\
Abor, (2005) & Ghana & - \\
(Hung, Albert, \& Eddie, 2002) & Hong Kong & \\
\hline
\end{tabular}

However, it is argued that study of direct leverage-performance relation is not useful as it depends on various contingencies and moderating factors (Farooq, Ashraf, \& Ahmad, 2014). Intensity and even direction of leverage-performance relation can change because of these contingencies factors. Very few studies considered 
these contingencies while studying leverage-performance relation. Farooq et al. (2014) and Jermias (2008) studied firm's strategy and market competition as moderator to the leverage-performance relation. Similarly, Gleason, Mathur, and Mathur (2000) found culture as important moderator to the leverage-performance relation. O'Brien (2003) and Yung-Chieh (2013) studied innovation strategy as moderating factor to the leverage-performance relation. Kongmanila and Kimbara (2007) explored leverage-performance relation to the contingency of ownership structure and management styles. Similarly, Rocca (2007) and Chao (2012) also find that corporate governance is one of important moderator to the leverage-performance relation. Muneer, Bajuri, and Saif-ur-Rehman (2013) found that agency cost moderates the leverage-performance relation.

Hence, these studies explored firm strategies, environment dynamics, corporate governance and agency cost as moderator to the leverage-performance relation. Costs and benefits of debt borrowings vary within these firm specific contingencies. It is argued that there are determinants of capital structure and studying leverage-performance-relation within the contingencies of these determinants provide more practical solution to debt financing. Literature of capital structure has explored a number of firm specific determinants where they explored which kind of firms deploying more or less debt borrowings.

However, it is more important to know that what will be the value of these kinds of firms who deployed debt financing or not. This can be done through studying leverage-performance relation to the contingency of these determinants of debt borrowings. The objective of this research is also to follow this integrated approach to firm specific determinants and their moderation to leverage-performance relation. Subsequent section will explore important firm specific determinants of debt and their theoretical moderating effect on leverage-performance relation.

Similarly, positive relation of growth can be explained through trade-off theory that argued that during high growth periods, firms deploy less debt due to increasing risk. On the contrary pecking order theory postulates that during high growth opportunities, internal funds become insufficient and firms deploy more debt to get benefits from available opportunities (Köksal \& Orman, 2015). The trade-off theory also postulates positive relation of tangibility as more tangible firms can deploy more debt to gain tax benefits at low cost by using their assets as collateral. However, pecking order theory postulates that high tangible firms contain less asymmetric information that makes the equity finance as more feasible option (Harris \& Raviv, 1990). Trade off theory also predicts that in case of availability of alternative tax shield such as depreciation, firms deploy less debt to gain tax benefits (Ghosh et al., 2011).

Table 2 provides the results of these determinants. One can find positive and negative relation of size and liquidity in most of developing countries. This implies that in general, larger firms are deploying more debt while more liquid firms are doing conversely in developing countries. It is because larger firms contain less asymmetric information and get better access to the debt market. However, more liquid firms contain more internal funds that are used as first preferred financing option. So, better access to the debt market and available internal funds can be the reason of positive and negative relation of size and liquidity respectively. Conversely, growth, tangibility and non-debt tax shield are showing more variations among different developing countries. So, it is difficult to draw general conclusion about these three determinants in case of developing economies.

However, the important thing is that if these larger firms deploy more debt and more liquid firms deploy less debt then what will be their value? Similarly, what will be the value of firms with growth, tangibility and non-debt tax shield who deployed and who do not deployed debt financing? Previously, these questions are answered theoretically and few studies provided empirical evidences. Moreover, those few studies explore determinants and their moderating effect to leverage-performance relation individually. No attention is given to study the combined effect of these determinants and their moderating role to leverage-performance relation. This research argued that it is more useful to study the combined effect as in practice firms contain different characteristics simultaneously. For instance, in practice larger firms can have more liquidity, high tangibility, more non-debt tax shield and less growth. How firms with these characteristics finance and what will be their value? The primary contribution of this study is to study this ignored area. 
Table 2. Determinants of leverage in developing countries

\begin{tabular}{|c|c|c|c|c|c|c|}
\hline Author \& Year & Country & Size & Growth & Tangibility & NDTS & Liquidity \\
\hline Imtiaz, Mahmud, \& Mallik, 2016 & Bangladesh & $?$ & $?$ & - & & $?$ \\
\hline (Balios, Daskalakis, Eriotis, \& Vasiliou, 2016) & Greece & + & + & - & & \\
\hline (Köksal \& Orman, 2015) & Turkey & + & $?$ & + & + & \\
\hline (Mohammad, 2015) & Iran & - & - & + & & - \\
\hline (Chandra, 2015) & Indonesia & - & - & - & & \\
\hline (Hossain \& Hossain, 2015) & Bangladesh & & - & - & - & - \\
\hline (Mangafić \& Martinović, 2015) & Bosnia and Herzegovina & $?$ & - & - & & \\
\hline (Al Ani \& Al Amri, 2015) & Oman & $?$ & - & + & & \\
\hline (Zerriaa \& Noubbigh, 2015) & Tunisia & + & $?$ & $?$ & - & \\
\hline (Chadha \& Sharma, 2015) & India & - & - & + & + & - \\
\hline (Vergas, Cerqueira, \& Brandão, 2015) & Portugal & $?$ & + & $?$ & + & \\
\hline (Ogbulu \& Emeni, 2012) & Nigeria & & + & + & & \\
\hline (González \& González, 2012) & Spanish & + & + & + & - & \\
\hline (Mouamer, 2011) & Palestine & + & - & + & & + \\
\hline (Baharuddin, 2011) & Malaysia & + & + & + & & \\
\hline (Sheikh \& Wang, 2011) & Pakistan & + & $?$ & - & $?$ & - \\
\hline (Chakraborty, 2010) & India & - & - & + & + & \\
\hline (Karadeniz et al., 2009) & Turkey & $?$ & $?$ & - & $?$ & \\
\hline (Omran \& Pointon, 2009) & Egypt & + & + & - & & - \\
\hline (Eriotis, Vasiliou, \& Ventoura-neokosmidi, 2007) & Greek & + & - & & & - \\
\hline (Delcoure, 2007) & Asia Pacific & + & - & + & + & \\
\hline
\end{tabular}

$?=$ insignificant results.

So, the objective of this research is twofold. The first part will explore that which kinds of Nonfinancial firms are deploying more debt and which others are doing conversely in Pakistan. Second part of this study will explore the moderating effect of these determinants to the leverage-performance relation. Particularly, the second part will also explore that for which kinds of firms, debt financing is more valuable option and for which kind of firms' debt financing harm their value in developing countries like Pakistan.

\section{Method}

\subsection{Data}

For analysis, panel data with 2557 observations from 304 Nonfinancial Pakistani firms listed with PSXfor the period of 2005 to 20013 is employed. Data is collected from the annual publication of Balance Sheet Analysis of Nonfinancial Firms Listed at Pakistan Stock Exchange (PSX) published by State Bank of Pakistan. This annual publication includes financial statement data of all listed Nonfinancial firms in Pakistan.Annual publications included data for 411 firms with total 3576 number of observations. However, a sample of 304 firms is selected after eliminating 118 default firms,firms with zero sales, firms with negative equity and 10 public firms. Table 3 shows the detail of the sample selection procedure. Data of public firms is eliminated because govt., owned and supports these firms and even provides funds from their budget. So, these public firms are highly leveraged. However, since govt., supports these firms in Pakistan so cost of financial distress for these public firms is relatively low. Their inclusion to final sample may provide biased results.

Table 3. Procedure of sample selection

\begin{tabular}{ccc}
\hline Steps & No. of Firms & Remaining Observations \\
\hline Initial Data of Nonfinancial Firms & 411 & 3576 \\
PSXDefault Data & 390 & 3424 \\
SBP Default Data & 358 & 2945 \\
Suspended From Listing & 349 & 2850 \\
Firms with Zero Sales & 335 & 2793 \\
Firms with Negative Equity & 314 & 2649 \\
Govt. Owned Firms & 304 & 2557 \\
\hline
\end{tabular}




\subsection{Models}

Since, the data is panel data, the fixed model is employed to achieve research objectives. Eq.-1 is showing the proposed model to study first objective of determinants of debt financing. This model will explore that in practice which kind of firms are deploying more debt and which others are doing conversely.

$$
\begin{aligned}
& D R_{i t}=\alpha+\beta_{1} \text { H.Size }_{i t}+\beta_{2} \text { L.Size }_{i t}+\beta_{3} \text { H.CR } \text { it }_{i t}+\beta_{4} \text { L.CR }_{i t}+\beta_{5} \text { H.Tang. }{ }_{\text {it }}+\beta_{6} \text { L.Tang. }_{\text {it }}+\beta_{7} \text { H.NDTS }_{i t}+ \\
& \beta_{8} L_{. N D T S}+\beta_{9} H . S G_{i t}+\beta_{10} L . S G_{i t}+U_{t}+V_{i}+\varepsilon_{i t}
\end{aligned}
$$

Where DRit (debt ratio ) is dependent variable and independent variables include dummy variables of high (H.) and low (L.) values of five determinants of size, current ratio, tangibility, non-debt tax shield and sales growth for firms $\mathrm{i}$ at year t. Table 4 shows detail of these variables.H.Size is a dummy variable of high size and calculated as dummy variable equal to 1 when variable of size lies in its fourth quartile and zero otherwise. Similarly, L.Size is calculated as dummy variable equal to 1 when variable of size lies in its first quartile and zero otherwise. Second and third quartile are considered as medium size firms and used as the reference category. All other variables are also segregated into dummy variables of high and low values with similar method. However, Ut and Vtrepresent the unobserved firm specific and time variant variations respectively.

Table 4. Definition of variables used

\begin{tabular}{lll}
\hline Abbreviation & Variables & Definition \\
\hline DR & Debt Ratio & Total Liabilities / Total Assets \\
Size & Size of Firm & Ln (Sales) \\
Tang. & Tangibility & Fixed Assets / Total Assets \\
CR & Current Ratio & Current Assets / Current Liabilities \\
NDTS & Non-Debt Tax Shield & Depreciation / Total Assets \\
SG & Sales Growth & Change in Sales \\
ROA & Return on Assets & EBT / Total Assets \\
\hline
\end{tabular}

Following Eq.-2 is proposed to study second objective that for which kinds of firms debt financing is a profitable option. ROA represents the proxy of profitability and used as dependent variable.Independent variables include the debt ratio and cross effect of debt ratio with different firm's characteristics.

$$
\begin{aligned}
& R O A=\alpha+\beta_{1} D R+\beta_{2} D R^{*} \text { H.Size }+\beta_{3} D R^{*} \text { L.Size }+\beta_{4} D R^{*} H . C R+\beta_{5} D R^{*} L . C R+\beta_{6} D R^{* H . T a n g} .+ \\
& \beta_{7} D R^{*} \text { L.Tang. }+\beta_{8} D R^{*} H . N D T S+\beta_{9} D R^{*} L . N D T S+\beta_{10} D R^{*} H . S G+\beta_{11} D R^{*} L . S G+U_{t}+V_{i}+\varepsilon_{i t}
\end{aligned}
$$

This proposed model will show the moderating effects of firms' characteristics on leverage-performance relation. The outcome of this model will show that for which kind of firms debt financing is profitable and for which kind of firms it harms their value.

\section{Results}

\subsection{Descriptive Analysis}

Table 5 shows, on average sampled firms have financed $57.5 \%$ of their assets through external borrowings and reported a 9.7\% return. This shows that more than half of assets are financed with debt borrowings. The results also reveal that on average, firms invested almost half (46.8\%) of their assets into tangible assets. It is also found that on average firms contain low liquidity (1.427). Though, current assets are 53.2\%, but current liabilities could be on higher side that eventually resulted in low liquidity. Moreover, on average depreciation expense is only 3.3\% of firms' total assets for sampled firms. This implies that depreciation as an alternative tax shield is limited for sampled firms. Mean sales growth for the period is $18.1 \%$ and shows that firms found high growth opportunities. So, on average sampled Nonfinancial firms contain high debt financing, low liquidity, low NDTS and high growth opportunities.

Table 5. Descriptive statistics

\begin{tabular}{lccccccc}
\hline & DR & ROA & CR & Tang. & NDTS & SG & Size \\
\hline $\mathbf{N}$ & 2557 & 2555 & 2540 & 2551 & 2530 & 2202 & 2557 \\
mean & 0.575 & 0.097 & 1.427 & 0.468 & 0.033 & 0.181 & 14.744 \\
SD & 0.204 & 0.121 & 1.301 & 0.223 & 0.018 & 0.391 & 1.661 \\
min & 0.006 & -0.135 & 0.077 & 0.001 & 0.000 & -1.459 & 5.075 \\
max & 1.0 & 32.373 & 14.600 & 0.997 & 0.156 & 2.896 & 19.334 \\
\hline
\end{tabular}




\subsection{Determinants of Capital Structure}

Table 6 provides the result of the fixed effect model proposed in Eq.-1. Since, F-statistic (35.2) is high, so the model is significant at $1 \%$. Moreover, adjusted R2 is also high and show that $45.28 \%$ variation in debt ratio are due to selected independent variables. Hausman test is also showing significant results that show that using fixed effect model is more appropriate as compared to random effects. Independent variables include dummy variables of high (fourth quartile) and low (first quartile) values of size, current ratio, tangibility, non-debt tax shield and sales growth. Medium values (third and fourth quartile) for these variables are considered as the reference category. Results showed, H.Size, H.CR, and H.Tang are showing significant negative effects while L.CR and L.Tang are positively related. However, results of H.Size, L.NDTS, H.NDTS, L.SG and H.SG are insignificant and show that they have no effects on debt.

Table 6. Determinants of debt financing

\begin{tabular}{cccccc}
\hline & Beta & t-value & Sig. & 95\% Conf. Interval \\
\hline (Intercept) & $0.5885^{* * *}$ & 68.7000 & 0.0000 & 0.5717 & 0.6053 \\
L.Size & 0.0005 & 0.0500 & 0.9570 & -0.0189 & 0.0200 \\
H.Size & $-0.0207 * *$ & -2.0700 & 0.0390 & -0.0403 & -0.0011 \\
L.CR & $0.0605^{* * *}$ & 8.9700 & 0.0000 & 0.0473 & 0.0737 \\
H.CR & $-0.1357^{* * *}$ & -17.8300 & 0.0000 & -0.1506 & -0.1208 \\
L.Tang & $0.0252^{* * *}$ & 2.9500 & 0.0030 & 0.0084 & 0.0419 \\
H.Tang & $-0.0187^{* * *}$ & -2.3700 & 0.0180 & -0.0342 & -0.0032 \\
L.NDTS & 0.0038 & 0.5300 & 0.5970 & -0.0103 & 0.0179 \\
H.NDTS & 0.0107 & 1.5800 & 0.1130 & -0.0026 & 0.0240 \\
L.SG & -0.0027 & -0.4900 & 0.6220 & -0.0132 & 0.0079 \\
H.SG & 0.0012 & 0.2100 & 0.8330 & -0.0096 & 0.0119 \\
Industry Dummy & Yes & & & & \\
Time Dummy & Yes & & & & \\
Adjusted R2 & $45.28 \%$ & & & & \\
F-Statistics & $35.2 * *$ & & & & \\
Hausman & $739.83 * *$ & & & & \\
\hline
\end{tabular}

* Significance at 10\%; ** Significance at 5\%; *** Significance at $1 \%$.

Thus, larger, high liquid and high tangible firms deploy less debt while low liquid and low tangible firms deploy more debt. Beta (0.5885) is showing the average debt ratio for firms with medium values of size, CR, Tang., NDTS and SG (i.e. reference categories). Accordingly, firms with high size, high CR and high tangibility use least average debt ratio of 0.4134 (0.5885 $-0.0207-0.1357-0.0187)$. Similarly, firms with medium or low size, low current ratio and low tangibility are deploying highest debt ratio of $0.6741(0.5885+0.0605+0.0252)$. These results are inconsistent with the pecking order theory. High size and high current ratio shows more availability of internal fund that is preferred as a first financing option. However, for small size and low liquidity firms, internal funds are inefficient and firms deploy more debt.

Similarly, negative relation of high tangibility can be explained from two perspectives. First, by pecking order theory that tangible firms are considered larger in size and contain less asymmetric information that could allow them to finance through equity without under-pricing (Harris \& Raviv, 1990). While another reason behind this negative relation can be agency problem. Titman and Wessels (1988) argued that managers can consume more than the optimal level of prerequisite that can ultimately result into negative relation between debt borrowings and tangibility. Nonetheless, argument given by agency theory seems to be more relevant as the governance regulations are not much stronger in Pakistan that makes more appropriate to accept argument given by Titman and Wessels (1988). Moreover, a negative relation can be due to firms' overreliance on short term liabilities for tangible assets as collateral is only important for long debt borrowings. Results of NDTS and SG are insignificant. This shows that there are no differences to the debt borrowing for high, low and medium values of NDTS and SG. In other words, these two factors do not affect firms' financing choices and among firms with high, low and medium values some deploy and some others do not deploy debt borrowings. Hence, this section finds two main implications. 1) Only size, liquidity and tangibility are important factors of debt borrowings in case of Pakistani Nonfinancial firms. 2) Large size, liquid and more tangible firms deployed least debt ratio on average, while low or medium size, low liquid and low tangible firms deployed maximum debt ratio on average. 


\subsection{Consequences of Financing Decision}

Table 7 provides the results of debt financing with contingency of its determinants. The proposed model is significant and showed a high F-value while adjusted R2 is also $26.44 \%$. The significant value of Hausman test also indicates that using fixed effect is more appropriate as compared to random effects. Proposed model includes debt ratio and its cross effects with firm characteristics. Beta coefficient of DR represents its slope in case of medium values of all determinants (reference category). This implies that with a unit change in DR profits will decrease by $27 \%$ for the firms having medium values of size, current ratio, tangibility, NDTS and growth. However, cross effects of DR with L.Size, L.CR, H.Tang and L.SG are showing significant negative betas. This implies that deploying more debt by firms having low size, low liquidity, high tangibility and low growth will further decrease profits. More precisely with a unit change in DR average profits will decrease by -0.426 or $42.6 \%(-0.270-0.021-0.037-0.052-0.046)$ when firms are low size, low liquid and more tangible with less growth opportunities. Conversely, cross effect of DR with H.Size, H.CR, L.Tang and H.SG are showis that deploying debt by high size, more liquid, less tangible and growth oriented firms will increase their profits comparatively. It is revealed that with these firm characteristics,s slope of DR will be $-0.158(-0.27+0.022+$ $0.029+0.031)$.

Table 7. Consequences of debt financing

\begin{tabular}{lccccc}
\hline & beta & z-value & Sig. & 95\% Conf. Interval \\
\hline Intercept & $0.243^{* * *}$ & 22.020 & 0.000 & 0.221 & 0.264 \\
DR & $-0.270^{* * *}$ & -14.290 & 0.000 & -0.308 & -0.233 \\
DR*L.Size & $-0.021^{*}$ & -1.820 & 0.069 & -0.043 & 0.002 \\
DR*H.Size & $0.022^{*}$ & 1.760 & 0.079 & -0.003 & 0.047 \\
DR*L.CR & $-0.037 * * *$ & -4.730 & 0.000 & -0.052 & -0.021 \\
DR*H.CR & $0.029^{* *}$ & 2.290 & 0.022 & 0.004 & 0.054 \\
DR*L.Tang & $0.030^{* * *}$ & 2.710 & 0.007 & 0.008 & 0.051 \\
DR*H.Tang & $-0.052^{* * *}$ & -5.480 & 0.000 & -0.070 & -0.033 \\
DR*L.NDTS & 0.006 & 0.660 & 0.510 & -0.012 & 0.024 \\
DR*H.NDTS & -0.013 & -1.590 & 0.113 & -0.030 & 0.003 \\
DR*L.SG & $-0.046^{* * *}$ & -6.700 & 0.000 & -0.060 & -0.033 \\
DR*H.SG & $0.031^{* * *}$ & 4.550 & 0.000 & 0.018 & 0.045 \\
Time Dummy & Yes & & & Model F-Value & 40.68 \\
Industry Dummies & Yes & & Hausman Chi2 & 54.9 \\
Adjusted R2 & $26.44 \%$ & & & & \\
\hline
\end{tabular}

* Significance at $10 \% ; * *$ Significance at $5 \% ; * * *$ Significance at $1 \%$.

Results of Size and Liquidity are consistent with the trade-off theory that argued that with less cost of financial distress larger and more liquid firms can get benefits of debt borrowings. However, negative results of high tangibility shows that firms are not getting debt benefits as they should. This negative relation can be explained with agency problem argument given by Titman and Wessels (1988) as advocated in previous section. Similarly, results of high sales growth are consistent with the view of using debt in case of insufficient internal funds to exploit available opportunities as argued by pecking order theory.However, results of NDTS are found insignificant that shows that profits of high, low and medium values of NDTS do not differ.In short, following targeted optimal capital structure as argued by trade-off theory is more favourable in case of Pakistani Nonfinancial firms.

It is also notable that though, cross effects of DR with high size, more liquid, less tangible and growth oriented firms are positive but still their combine effect leads to negative slope. In developing countries, agency problem is more prominent. Consequently, firms often become over-leveraged and deviate from optimal level. This leads to negative leverage-performance relation in developing countries. So, the overall negative slope of DR for high size, more liquid, less tangible and growth oriented firms can also be due to be over-leveraged to deviate from the optimal level in case of Pakistani Nonfinancial firms. Linking these results to previous section, one can identify that in practice, whether financing decisions are optimal or not. Highlighted areas of Table 8 show unfavourable financing decisions followed in real practice. Results have shown that in practice large size, more liquid and more tangible firms are deploying least debt ratio.However, deploying debt by large size and more liquid firms is found profitable comparatively. Thus, in practice deploying least debt by larger and more liquid 
firms is not an optimal decision. Similarly, in practice low liquid and low tangible firms deployed maximum debt ratio on average. However, deploying more debt by less liquid firms is not found optimal. This shows that in practice, managers of such Nonfinancial firms in Pakistan need to revise their financing strategy.

Table 8. Summary of results

\begin{tabular}{lccccc}
\hline & Trade-off & Pecking Order & Developing Countries research & Results as Determinants & Profitability with debt \\
\hline High Size & + & - & + & - & + \\
Low Size & - & + & - & $?$ & - \\
High Liquidity & + & - & + & - & + \\
Low Liquidity & - & + & Mix & + & - \\
High Tangibility & + & - & Mix & + & - \\
Low Tangibility & - & + & Mix & $?$ & $?$ \\
High NDTS & - & & Mix & $?$ & $?$ \\
Low NDTS & + & - & Mix & $?$ & + \\
High Growth & - & + & Mix & $?$ & - \\
Low Growth & + & - & & $?$ \\
\hline
\end{tabular}

? Refers to insignificant results.

Highlighted area shows unfavourable financing decisions in real practice.

Hence, this section also concludes several implications. 1) Debt borrowings by categorize with small size, less liquidity, more tangible and less growth harm their profits most severely. 2) Debt borrowings by larger, more liquid, less tangible and growth oriented firms is found the most profitable decision comparatively. 3) The overall effect of debt for larger, more liquid, less tangible and growth oriented firms is still found negative. 4) In practice deploying less debt by larger and more liquid firms is not an optimal decision. 5) In practice deploying more debt by less liquid is also not an optimal decision.

\section{Conclusion}

This study tried to explain that which kinds of firms deploy more debt and which others do conversely in developing countries like Pakistan and whether such financing decisions are favourable or not. These objectives are attained through studying firm specific determinants of debt borrowings and their moderating role to leverage-performance relation. It is argued that firm specific determinants of debt borrowings are more important as it shows that in practice which kinds of firms are deploying more debt and which others are doing conversely. It is found that in Pakistani Nonfinancial larger, more liquid and less tangible firms are deploying least debt ratio comparatively. However, less liquid and less tangible firms are deploying most debt borrowings on average. Conversely, less liquid and less tangible firms deployed most high debt ratio on average. Thus, it appears that Nonfinancial firms are following pecking order theory in practice. The results also revealed that firms which are large, more liquid and less tangible with more growth opportunities should deploy debt borrowings as it effect their value positively. However, it is also important that such firms should not be over-leveraged to deviate from their optimal level. Furthermore, smaller, less liquid, more tangible and less growth oriented firms should avoid debt borrowings as it affects their value most severely. This research also concluded that in practice larger and more liquid firms who are deploying less debt while less liquid firms who are deploying more debt are not following optimal decision making. Financial managers of such kinds of firms should revise their financing policy and try to target optimal level accordingly. So, this study has strong practical implications that explored that in practice which kinds of firms are deploying debt and which kind of firms should deploy more debt and vice versa.

\section{References}

Abor, J. (2005). The effect of capital structure on profitability: An empirical analysis of listed firms in Ghana. The Journal of Risk Finance, 6(5), 438-445. http://dx.doi.org/10.1108/15265940510633505

Akinlo, O., \& Asaolu, T. (2012). Profitability and leverage: Evidence from nigerian firms. Global Journal of Business Research, 6(1), 17-25.

Al Ani, M., \& Al Amri, M. (2015). The Determinants of Capital Structure: An Empirical Study of Omani Listed Industrial Companies. Business: Theory and Practice, 16(2), 159-167. http://dx.doi.org/10.3846/btp.2015.471 
Alipour, M., \& Pejman, M. E. (2015). The impact of performance measures, leverage and efficiency on market value added: Evidence from Iran. Global Economics and Management Review, 20(1), 6-14. http://dx.doi.org/10.1016/j.gemrev.2015.04.001

Baharuddin, N. S. (2011). Determinants of Capital Structure for Listed Construction Companies in Malaysia. Journal of Applied Finance \& Banking, 1(2), 115-132.

Balios, D., Daskalakis, N., Eriotis, N., \& Vasiliou, D. (2016). SMEs capital structure determinants during severe economic crisis: The case of Greece. Cogent Economics \& Finance, 4(1), 1-11. http://dx.doi.org/10.1080/23322039.2016.1145535

Baral, K. J. (2004). Determinants of Capital Structure : A Case Study of Listed Companies of Nepal. The Journal of Nepalese Business Studies, I(1), 1-13.

Boadi, E. K., \& Li, Y. (2015). An Empirical Analysis of Leverage and Financial Performance of Listed Nonfinancial Firms in Ghana. International Journal of Economics and Finance, 7(9), 120-135. http://dx.doi.org/10.5539/ijef.v7n9p120

Boateng, A. (2004). Determinants of capital structure: Evidence from international joint ventures in Ghana. International Journal of Social Economics, 31(1/2), 56-66. http://dx.doi.org/10.1108/03068290410515411

Bokpin, G. A., \& Arko, A. C. (2009). Macroeconomic development and capital structure decisions of firms Evidence from emerging market economies. Studies in Economics and Finance, 26(4), 246-256. http://dx.doi.org/10.1108/10867370910995708

Brealey, R., \& Mayers, S. (2003). Principles of Corporate Finance (7th ed.). McGraw-Hill. http://dx.doi.org/10.1007/s13398-014-0173-7.2

Chadha, S., \& Sharma, A. (2015). Determinants of capital structure: An empirical evaluation from India. Journal of Advances in Management Research, 12(1), 3-14. http://dx.doi.org/10.1108/JAMR-08-2014-0051

Chakraborty, I. (2010). Capital structure in an emerging stock market: The case of India. Research in International Business and Finance, 24(3), 295-314. http://dx.doi.org/10.1016/j.ribaf.2010.02.001

Chandra, T. (2015). The Determinants of the Capital Structure: Empirical Evidence from Indonesian Stock Exchange Companies. Revista Kasmera, 43(2), 76-87.

Chao, C. (2012). The Influence of Capital Structure on Organizational Performance at Taiwan-Listed Info-Electronics Companies: Using Corporate Governance as the Moderator. American Journal of Business and Management, $\quad$ l(2), 60-69. $\quad$ Retrieved from http://www.worldscholars.org/index.php/ajbm/article/view/09

Chen, J., \& Strange, R. (2005). The determinants of capital structure: Evidence from Chinese listed companies. Economic Change and Restructuring, 38, 11-35. http://dx.doi.org/10.1007/s10644-005-4521-7

Chen, J., Chen, M., Liao, W., \& Chen, T. (2009). Influence of capital structure and operational risk on profitability of life insurance industry in Taiwan. Journal of Modelling in Management, 4(1), 7-18. http://dx.doi.org/10.1108/17465660910943720

Cook, D. O., \& Tang, T. (2010). Macroeconomic conditions and capital structure adjustment speed. Journal of Corporate Finance, 16(1), 73-87. http://dx.doi.org/10.1016/j.jcorpfin.2009.02.003

Delcoure, N. (2007). The determinants of capital structure in transitional economies. International Review of Economics and Finance, 16(3), 400-415. http://dx.doi.org/10.1016/j.iref.2005.03.005

Ebaid, I. E. (2009). The impact of capital-structure choice on firm performance: Empirical evidence from Egypt. The Journal of Finance, 10(5), 477-487. http://dx.doi.org/10.1108/15265940911001385

Eldomiaty, T. I. (2007). Determinants of corporate capital structure: Evidence from an emerging economy. International Journal of Commerce and Management, 17(1/2), 25-43. http://dx.doi.org/10.1108/10569210710774730

Eriotis, N., Vasiliou, D., \& Ventoura-neokosmidi, Z. (2007). empirical study How firm characteristics affect capital structure: An empirical study. Managerial Finance, 33(5), 321-331. http://dx.doi.org/10.1108/03074350710739605

Farooq, U., Ashraf, A. A., \& Ahmad, N. (2014). Investigating the Moderating Role of Firm Strategy in the Relationship Between Leverage and Performance. Middle-East Journal of Scientific Research, 21(2), 341-346. http://dx.doi.org/10.5829/idosi.mejsr.2014.21.02.1767 
Ghosh, S., Harrington, C., \& Smith, W. (2011). Do windfall non-debt tax shields from acquisitions affect corporate debt issues? Managerial Finance, 37(6), 537-552. http://dx.doi.org/10.1108/03074351111134736

Gleason, K. C., Mathur, L. K., \& Mathur, I. (2000). The Interrelationship between Culture, Capital Structure, and Performance: Evidence from European Retailers. Journal of Business Research, 50, 185-191. http://dx.doi.org/10.1016/S0148-2963(99)00031-4

González, V. M., \& González, F. (2012). Firm size and capital structure: Evidence using dynamic panel data. Applied Economics, 44(36), 4745-4754. http://dx.doi.org/10.1080/00036846.2011.595690

Hailu, A. (2015). The impact of capital structure on profitability of Commercial Banks in Ethiopia. Addis Ababa University.

Harris, M., \& Raviv, A. (1990). Capital structure and the informational role of debt. Journal of Finance, 45, 321-349. http://dx.doi.org/10.1111/j.1540-6261.1990.tb03693.x

Hedayatzadeh, S. H. A. (2015). The relationship between capital structure and corporate performance of pharmaceutical accepted in the Tehran stock exchange. Journal of Scientific Research and Development, 2(1), 208-216.

Horizons, E., Chowdhury, A., \& Chowdhury, S. P. (2010). Impact of capital structure on firm's value: Evidence from Bangladesh. Business and Economic Horizons, 3(3), 111-112.

Hossain, I., \& Hossain, A. (2015). Determinants of Capital Structure and Testing of Theories: A Study on the Listed Manufacturing Companies in Bangladesh. International Journal of Economics and Finance, 7(4), 176-190. http://dx.doi.org/10.5539/ijef.v7n4p176

Hung, C. Y., Albert, C. P. C., \& Eddie, H. C. M. (2002). Capital structure and profitability of the property and construction sectors in Hong Kong. Journal of Property Investment \& Finance, 20(6), 434-453. http://dx.doi.org/10.1108/14635780210446469

Imtiaz, F., Mahmud, K., \& Mallik, A. (2016). Determinants of Capital Structure and Testing of Applicable Theories: Evidence from Pharmaceutical Firms of Bangladesh. International Journal of Economics and Finance, 8(3), 23-32. http://dx.doi.org/10.5539/ijef.v8n3p23

Jensen, M., \& Meckling, W. (1976). Theory of the firm, managerial behavior, agency costs and ownership structure. Journal of Financial Economics, 3(1), 30-60. http://dx.doi.org/10.1016/0304-405x(76)90026-x

Jermias, J. (2008). The relative influence of competitive intensity and business strategy on the relationship between financial leverage and performance. The British Accounting Review, 40, 71-86. http://dx.doi.org/10.1016/j.bar.2007.11.001

Karadeniz, E., Kandir, S. Y., Balcilar, M., \& Beyazit Onal, Y. (2009). Determinants of capital structure: Evidence from Turkish lodging companies. International Journal of Contemporary Hospitality Management, 21(5), 594-609. http://dx.doi.org/10.1108/09596110910967827

Köksal, B., \& Orman, C. (2015). Determinants of capital structure: Evidence from a major developing economy. Small Business Economics, 44(2), 255-282. http://dx.doi.org/10.1007/s11187-014-9597-x

Kongmanila, X., \& Kimbara, T. (2007). Corporate financing and performance of SMEs: The moderating effects of ownership types and management styles. The Journal of the Malaysian Institute of Management, 42(2), 119-133. Retrieved from http://portal.mim.org.my/resources/mmr/2007/CorpFinancing.pdf

Mackay, P., \& Phillips, G. M. (2005). How Does Industry Affect Firm Financial Structure ? Advance Access Publication, 18(4), 1433-1466. http://dx.doi.org/10.1093/rfs/hhi032

Majumdar, S., \& Chhibber, P. (1999). Capital structure and performance: Evidence from a transition economy on an aspect of corporate governance. Public Choice, 98(1), 287-305. http://dx.doi.org/10.1023/A:1018355127454

Mangafić, J., \& Martinović, D. (2015). The Firm-Specific Determinants of the Target Capital Structure: Evidence from Bosnia and Herzegovina Panel Data. Mediterranean Journal of Social Sciences, 6(2), 188-198. http://dx.doi.org/10.5901/mjss.2015.v6n2s5p188

Memon, F., Bhutto, N., \& Abbas, G. (2012). Capital structure and firm performance: A case of textile sector of Pakistan. Asian Journal of Business and Management Sciences, 1(9), 9-15. Retrieved from http://www.ajbms.org/articlepdf/ajbms20129i1808.pdf

Modigliani, F., \& Miller, M. (1958). The cost of capital, corporate finance and the theory of investment. 
American Economic Review, 48(1), 261-297.

Mohammad, A. (2015). Determinants of capital structure: An empirical study of firms in Iran. International Journal of Law and Management, 57(1), 53-83. http://dx.doi.org/10.1108/03074351111103668

Mouamer, F. M. A. (2011). The determinants of capital structure of Palestine-listed companies. The Journal of Risk Finance, 12(3), 226-241. http://dx.doi.org/10.1108/15265941111136969

Mule, R. K., \& Mukras, M. S. (2015). Financial leverage and performance of listed firms in a frontier market: Panel evidence from Kenya. European Scientific Journal, 11(7), 547-563.

Muneer, S., Bajuri, N. H., \& Saif-ur-Rehman. (2013). Moderating effect of agency cost on the relationship between capital structure, dividend policy and organization performance: A brief literature review. Actual Problems of $\quad$ Economics, 11(149), $\quad 434-442 . \quad$ Retrieved from http://www.irbis-nbuv.gov.ua/cgi-bin/irbis_nbuv/cgiirbis_64.exe?C21COM=2\&I21DBN=UJRN\&P21DBN

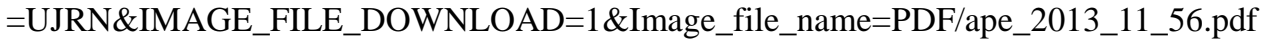

Myers, \& Majluf, N. (1984). Corporate financing and investment decisions when firms have information that investors do not have. Journal of Financial Economics, 13(1), 187-221. http://dx.doi.org/10.1016/0304-405X(84)90023-0

Myers, S. C. (1984). The Capital Structure Puzzle. The Journal of Finance, 39(3), 575-592. http://dx.doi.org/10.2307/2327916

Nakhaei, M., \& Jafari, S. M. (2015). Survey of the Relationship between Capital Structure and Free Cash Flow with Financial Performance of Companies Listed in Tehran Stock Exchange. Indian Journal of Science and Technology, 8(27), 1-11. http://dx.doi.org/10.17485/ijst/2015/v8i27/82813

Nguyen, T., \& Nguyen, H. C. (2015). Capital Structure and Firms' Performance: Evidence from Vietnam's Stock Exchange. International Journal of Economics and Finance, 7(12), 1-10. http://dx.doi.org/10.5539/ijef.v7n12p1

O'Brien, J. (2003). The capital structure implication of pursuing a strategy of innovation. Strategic Management Journal, 24(2), 415-431. http://dx.doi.org/10.1002/smj.308

Ogbulu, O. M., \& Emeni, F. K. (2012). Determinants of Corporate Capital Structure in Nigeria. Management, 1(10), 81-96.

Omran, M. M., \& Pointon, J. (2009). Capital structure and firm characteristics: An empirical analysis from Egypt. Review of Accounting and Finance, 8(4), 454-474. http://dx.doi.org/10.1108/14757700911006976

Ramadan, Z. S., \& Ramadan, I. Z. (2015). Capital Structure and Firm's Performance of Jordanian Manufacturing Sector. International Journal of Economics and Finance, 7(6), 279-284. http://dx.doi.org/10.5539/ijef.v7n6p279

Resić, E., Mangafić, J., \& Peric, T. (2015). Statistical analysis of causality between capital structure and firm profitability: Evidence from Bosnia and Herzegovina. Croatian Review of Economic, Business and Social Statistics, 1(1), 1-11.

Rocca, M. La. (2007). The influence of corporate governance on the relation between capital structure and value. Corporate Governance, 7(3), 312-325. http://dx.doi.org/10.1108/14720700710756580

Rouf, M. A. (2015). Capital Structure and Firm Performance of Listed Nonfinancial Companies in Bangladesh. The International Journal of Applied Economics and Finance, 9(1), 25-32. http://dx.doi.org/10.3923/ijaef.2015.25.32

Sheikh, N. A., \& Wang, Z. (2011). Determinants of capital structure: An empirical study of firms in manufacturing industry of Pakistan. Managerial Finance, 37(2), 117-133. http://dx.doi.org/10.1108/03074351111103668

Sheikh, N. A., \& Wang, Z. (2012). Effects of corporate governance on capital structure: Empirical evidence from Pakistan. Corporate Governance, 12(5), 629-641. http://dx.doi.org/10.1108/14720701211275569

Titman, S., \& Wessels, R. (1988). The Determinants of Capital Structure Choice. The Journal of Finance, 43(1), 1-19. http://dx.doi.org/10.1111/j.1540-6261.1988.tb02585.x

Umar, M., Tanveer, Z., Aslam, S., \& Sajid, M. (2012). Impact of Capital Structure on Firms' Financial Performance: Evidence from Pakistan. Research Journal of Finance and Accounting, 3(9), 1-13.

Vătavu, S. (2015). financial performance in Romanian listed companies. Procedia Economics and Finance, 
32(3), 1314-1322. http://dx.doi.org/10.11648/j.jfa.20150303.13

Vergas, N., Cerqueira, A., \& Brandão, E. (2015). The Determinants of the Capital Structure of Listed on Stock Market Non fnancial Firms: Evidence for Portugal (No. 555).

Vithessonthi, C., \& Tongurai, J. (2015). The effect of leverage on performance: Domestically-oriented versus internationally-oriented firms. Research in International Business and Finance, 34, 265-280. http://dx.doi.org/10.1016/j.ribaf.2015.02.016

Yung-Chieh, C. (2013). The effects of capital structure on the corporate performance of Taiwan-listed photovoltaic companies: A moderator of corporate innovation activities. Journal of Global Business Management, 9(1), 92-105. $\quad$ Retrieved from http://search.proquest.com/openview/4d37006874d67ead4fae7cbf5216f0ef/1 ?pq-origsite=gscholar

Zaher, T. S. (2010). Performance of debt free firms. Managerial Finance, 36(6), 491-501. http://dx.doi.org/10.1108/03074351011042973

Zeitun, R., \& Tian, G. G. (2007). Capital structure and corporate performance: Evidence from Jordan. Australasian Accounting Business and Finance Journal, 1(4), 40-61.

Zerriaa, M., \& Noubbigh, H. (2015). Determinants of Capital Structure: Evidence from Tunisian Listed Firms.

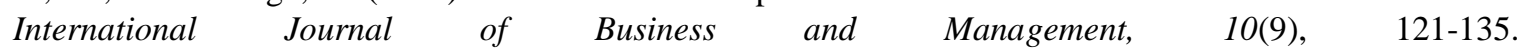
http://dx.doi.org/10.5539/ijbm.v10n9p121

\section{Copyrights}

Copyright for this article is retained by the author(s), with first publication rights granted to the journal.

This is an open-access article distributed under the terms and conditions of the Creative Commons Attribution license (http://creativecommons.org/licenses/by/3.0/). 